\title{
AKTIVITAS ANTIOKSIDAN MADU HUTAN DI BEBERAPA KECAMATAN DI KABUPATEN SUMBAWA BESAR
}

\author{
Dinar Suksmayu Saputri, Yolli Eka Putri \\ Fakultas Teknologi Pertanian Universitas Teknologi Sumbawa
}

\begin{abstract}
ABSTRAK
Madu merupakan zat alami yang dihasilkan oleh lebah madu dari nektar bunga dan sekresi tanaman. Madu mengandung mineral, protein, vitamin, asam organik, flavonoid, senyawa fenolik, dan enzim seperti katalase, peroksida, glukosa oksidasi, dan fitokimia lainnya, madu juga memiliki aktivitas antioksidan enzimatik dan non-enzimatik. Komposisi utama madu terdiri dari 80\% karbohidrat, 17-20\% air, 1-2\% mineral dan senyawa organik. Penelitian ini bertujuan untuk identifikasi kandungan antioksidan pada madu hutan di beberapa daerah di Kabupaten Sumbawa. Untuk identifikasi kandungan antioksidan dilakukan analisa aktivitas antioksidan, total fenol, ekstraksi senyawa fenolik, dan identifikasi senyawa fenolik pada madu. Jumlah sampel yang digunakan adalah sampel madu yang diperoleh dari 2 lokasi hutan di Kecamatan Batu Lanteh, 1 lokasi hutan Kecamatan Labuhan Badas dan 1 lokasi hutan Kecamatan Lape Kabupaten Sumbawa. Hasil dari penelitian menunjukkan bahwa madu hutan di beberapa daerah tersebut mengandung senyawa fenol (asam galat) sebesar 0,0633 - 0,3875 $\mathrm{mg} / \mathrm{g}$ dan memiliki aktivitas antioksidan antara 3,3365 - 30,9680\% dengan nilai IC50 60,2 - 572,3 $\mathrm{mg} / \mathrm{mL}$.
\end{abstract}

Kata kunci: madu hutan, antioksidan, Sumbawa

\section{PENDAhUluan}

Madu merupakan zat alami yang dihasilkan oleh lebah madu dari nektar bunga dan sekresi tanaman. Madu diketahui memiliki aktivitas antioksidan enzimatik dan nonenzimatik. Selain itu, madu merupakan larutan gula yang sangat jenuh, madu juga mengandung mineral, protein, vitamin, asam organik, flavonoid, senyawa fenolik, dan enzim seperti katalase, peroksida, glukosa oksidasi, dan fitokimia lainnya. Tergantung pada kondisi geografis dan iklim, berbagai jenis madu mengandung berbagai fitokimia termasuk polifenol dan asam fenolik yang berperan sebagai antioksidan. Polifenol utama dalam madu adalah flavonoid dengan kandungan yang bebeda-beda antara 60 dan $460 \mu \mathrm{g}$ per $100 \mathrm{~g}$ madu (Sime et al, 2007).

Penelitian mengenai madu telah banyak dilakukan, namun penelitian dan kajian khusus madu lokal yang dihasilkan dari lebah madu Indonesia khususnya Pulau Sumbawa masih jarang ditemukan. Selain itu, penelitian dan kajian mengenai madu lokal ini menjadi penting karena komposisi madu, termasuk kandungan antioksidan, dipengaruhi oleh perbedaan jenis tanaman, iklim, dan kondisi lingkungan. Hutan pulau Sumbawa yang luas dan subur merupakan sumber makanan yang berlimpah bagi lebah penghasil madu. Madu hutan di pulau Sumbawa sebagian besar di hasilkan oleh jenis lebah Apis dorsata.

Mengambil madu di hutan merupakan mata pencaharian sampingan bagi para petani di pulau Sumbawa. Madu hutan Sumbawa telah dipercaya sejak dahulu memiliki manfaat yang baik untuk kesehatan. Melalui penelitian ini diharapkan dapat membuktikan aktivitas antioksidan madu hutan Sumbawa. Dengan diketahuinya aktivitas antioksidan madu Sumbawa dalam menangkal radikal bebas, diharapkan akan meningkatkan nilai ekonomi madu Sumbawa dan memberi informasi lebih detail pada konsumen tentang fungsi madu Sumbawa bagi kesehatan.

\section{METODE PENELITIAN}

\section{A. Waktu dan Lokasi}

Penelitian dilakukan di Laboratorium

Pangan Terpadu Universitas Teknologi Sumbawa, Laboratorium Analisis Terpadu Fakultas Teknologi Pertanian Universitas Jember dan Laboratorium Pengujian Mutu dan Keamanan Pangan Jurusan THP FTP Universitas Brawijaya. Jadwal penelitian dimulai bulan Januari 2017, berakhir pada November 2017.

\section{B. Bahan dan Alat}

Bahan yang digunakan adalah madu hutan dari Kecamatan Lape, Tepal, Punik dan Pulau Moyo. Bahan kimia yang digunakan antara lain reagen Folin - Ciocalteau, $\mathrm{Na}_{2} \mathrm{CO}_{3}$, asam galat, reagen DPPH, $0,1 \mathrm{~N} \mathrm{HCl}$, $\left(\mathrm{NH}_{4}\right)_{2} \mathrm{SO}_{4}$, indicator amilum dan iodin $0,1 \mathrm{~N}$. Alat yang digunakan dalam penelitian ini antara 
lain tabung reaksi, beaker glass, spektrofotometer, buret, pipet, neraca analitik, dll.

\section{Tahapan Penelitian}

Analisa Aktivitas Antioksidan (Chua, L.S. et al., 2013)

$0,75 \mathrm{~mL}$ larutan madu dan methanol dengan konsentrasi $20-40 \mathrm{mg} / \mathrm{mL}$ ditambahkan $1,5 \mathrm{~mL}$ larutan DPPH, lalu diukur absorbansinya pada panjang gelombang $517 \mathrm{~nm}$.

Analisa Total Fenol (Marshall, S.M., 2013)

5 g madu dilarutkan dengan $25 \mathrm{~mL}$ aquadest. Setiap sampel lalu ditambahkan reagen FolinCiocalteau dan $\mathrm{Na}_{2} \mathrm{CO}_{3} \quad(15 \%)$. Larutan diinkubasi pada suhu ruang selama 30 menit dan diukur absorbansinya pada panjang gelombang $765 \mathrm{~nm}$.

Analisa Vitamin C (Siti, N. dkk., 2016)

$10 \mathrm{~g}$ madu dimasukkan dalam labu takar $50 \mathrm{~mL}$ dan ditambahkan aquades sampai garis batas. Sampel disaring untuk memisahkan filtratnya. $5 \mathrm{~mL}$ filtrate diambil menggunakan pipet volume, dimasukkan dalam erlenmeyer, ditambahkan 2 tetes larutan amilum dan $20 \mathrm{~mL}$ aquadest. Sampel dititrasi dengan larutan iodium $0,1 \mathrm{~N}$ sampai warna berubah menjadi biru mantap.
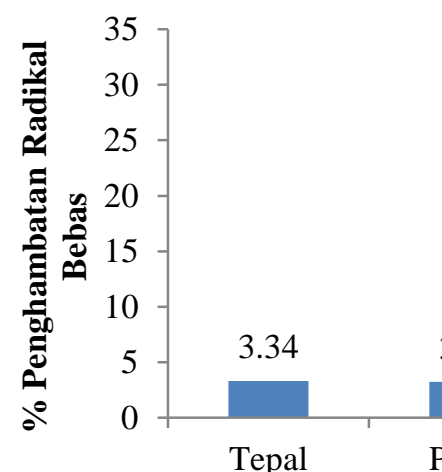

\section{HASIL DAN PEMBAHASAN}

Aktivitas Antioksidan

Analisa aktivitas antioksidan madu dilakukan menggunakan metode DPPH (2,2Diphenyl- 1-picrylhydrazyl). DPPH adalah radikal bebas yang stabil di suhu ruang dan menghasilkan larutan berwarna ungu dalam alkohol. DPPH akan tereduksi dengan adanya antioksidan. Analisa aktivitas antioksidan pada sampel madu ditentukan berdasarkan kemampuan antioksidan pada madu untuk melawan radikal bebas (DPPH). Elektron pada DPPH yang tidak berpasangan akan membentuk ikatan dengan hidrogen yang didonasikan oleh antioksidan pada madu. Reaksi ini akan mengubah warna ungu pada larutan DPPH menjadi kuning. Derajat perubahan warna ini diukur menggunakan spektrofotometer UV-visible untuk menentukan aktivitas antioksidan madu (Pontis, J.A. et al., 2014; Chua et al., 2013).

Dari hasil analisa didapatkan bahwa persen penghambatan madu Sumbawa terhadap radikal bebas sebesar 3,34\% untuk madu daerah Tepal, 3,24\% madu Punik, 9,87\% madu Lape dan 30,97\% madu Pulau Moyo. Persen penghambatan radikal bebas oleh madu Sumbawa dapat dilihat pada grafik di bawah,

30.97

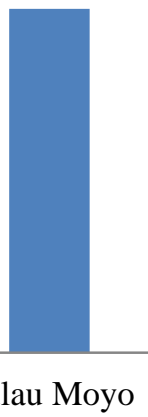

Lape Pulau Moyo

Gambar 4. Aktivitas Antioksidan Madu Sumbawa

Hasil tersebut menunjukkan bahwa aktivitas antioksidan sampel madu yang diambil dari beberapa daerah di Sumbawa tersebut lebih kecil daripada madu-madu dalam penelitian lain. Moniruzzaman et al. (2013) menganalisa madu dari lebah Apis dorsata di Malaysia mendapatkan persen penghambatan radikal bebas sebesar 59,89\%. Chayati $d k k$. (2014) mendapatkan aktivitas antioksidan sebesar 21,06 - 32,14\% pada madu di daerah Jawa dan Sumatera. Husein et al. (2011) mendapatkan aktivitas antioksidan madu dari pohon gelam dan nanas di Malaysia sebesar 17,7 82,68\%. Hasil ini juga lebih kecil daripada madu India (57,5\%), madu Algeria (44,55\%). Aktivitas antioksidan suatu bahan dipengaruhi oleh kandungan senyawa fitokimia yang memiliki sifat antioksidan. Senyawa tersebut diantaranya adalah asam fenolik, flavonoid, enzim (glukosa oksidase dan katalase), asam askorbat, karotenoid, asam organik, asam amino dan protein. Aktivitas antioksidan komponen fenolik berkontribusi terhadap kesehatan manusia (Khalil, M.I. et al., 2010). 
Aktivitas antioksidan juga dinyatakan dalam parameter IC50. IC50 menyatakan konsentrasi sampel yang dibutuhkan untuk menghambat 50\% radikal bebas, yang dalam hal ini adalah DPPH. Semakin rendah nilai IC50, maka konsentrasi sampel yang digunakan untuk menangkal 50\% radikal bebas semakin kecil, yang berarti sampel tersebut lebih kuat dalam menangkal radikal bebas (Pontis $e t$ al. 2014). Nilai IC50 sampel madu dari beberapa kecamatan di Sumbawa dapat dilihat pada grafik di bawah:

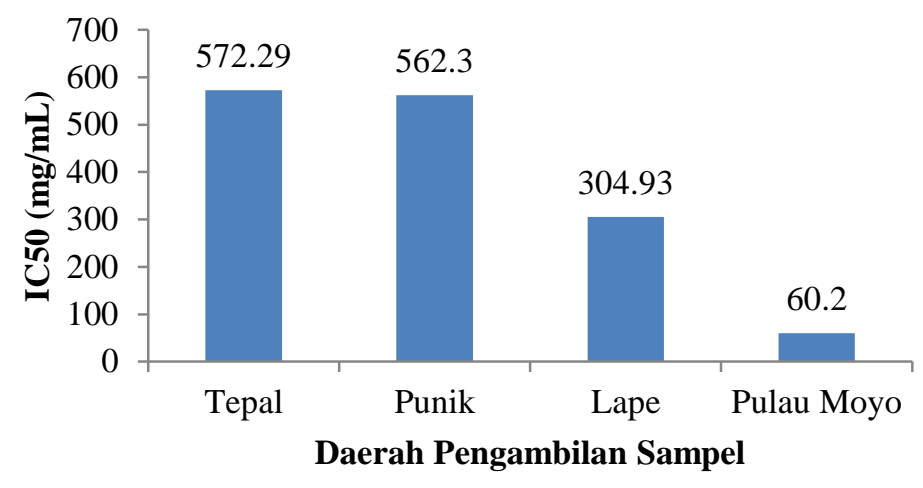

\section{Total Fenol}

Gambar 4. Nilai IC50 Madu Sumbawa

Analisa kandungan senyawa fenolik menggunakan metode Follin-Ciocalteau. Reaksi antara reagen Follin-Ciocalteau dengan senyawa fenolik akan membentuk warna biru kompleks yang dapat menyerap radiasi sehingga bisa diukur (Pontis, J.A. et al., 2014). Standar senyawa fenol yang digunakan dalam analisa ini adalah asam galat. Dari hasil analisa didapatkan total fenol madu dari Tepal sebesar 0,0704 mg/g, dari Punik 0,063 mg/g, dari Lape 0,2927 mg/g dan dari Pulau Moyo sebesar 0,3875 mg/g.

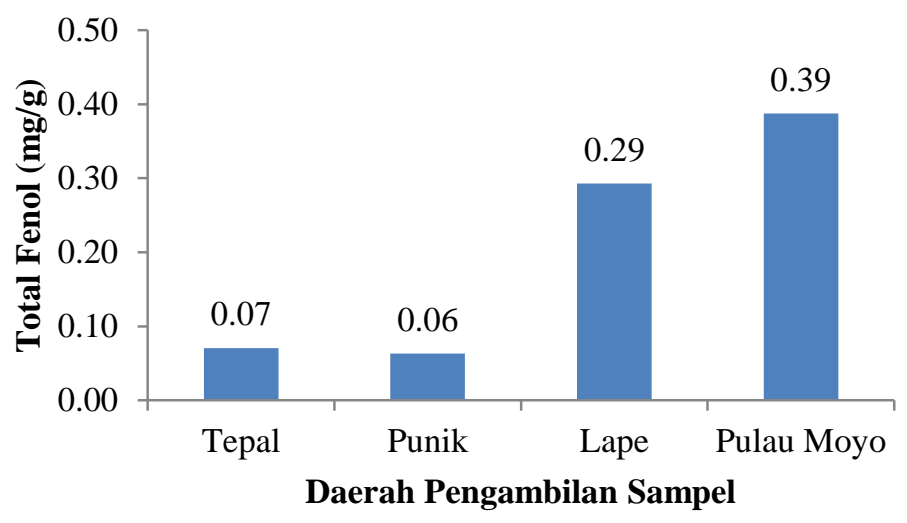

Gambar 5. Total Fenol (mg/g) madu Sumbawa

Nilai total fenol madu yang diambil dari beberapa daerah di Sumbawa ini hampir sama dengan hasil penelitian madu lain. Khalil et al. (2012) meneliti madu tualang dari Malaysia mendapatkan total fenol madu sebesar 0,22 - 0,38 mg/g. Kumazawa et al. (2012) menganalisa madu multifloral di Jepang dan mendapatkan total fenol sebesar 0,17-1,32 $\mathrm{mg} / \mathrm{g}$; madu Portugis $0,23-0,73 \mathrm{mg} / \mathrm{g}$ (Ferreira et al., 2009); madu dari Echium vulgare $0,29 \mathrm{mg} / \mathrm{g}$ (Nagai et al., 2012); madu Czech 0,03-0,16 mg/g (Lachman et al., 2010); madu Brazil 0,25 - $0.54 \mathrm{mg} / \mathrm{g}$ (Pontis et al., 2014).
Walaupun nilai total fenol madu Sumbawa tidak jauh berbeda dengan madu dari daerah lain, tetapi aktivitas antioksidannya sangat kecil apabila dibandingkan dengan penelitian lain. Hal ini disebabkan karena banyak gangguan dalam metode Follin Ciocalteau. Gangguan pada metode ini diantaranya adalah reagen Follin-Ciocalteau (campuran asam phosphotungstic dan phosphomolibdic) yang juga bereaksi dengan senyawa selain senyawa fenol seperti vitamin $C$, sehingga hasil total fenol menjadi berlebihan. Senyawa pereduksi lain seperti gula dan asam amino juga dapat mengganggu 
analisa. Hal ini menyebabkan kesalahan positif (positive error) pada hasil (Ferreira et al., 2009). Kandungan senyawa fenol dan aktivitas antioksidan pada madu berbanding lurus dengan warna madu. Warna madu berhubungan dengan keberadaan pigmen seperti karotenoid dan flavonoid. Madu yang berwarna lebih gelap memiliki total fenol dan aktivitas antioksidan lebih tinggi (Kumazawa et al., 2012). Teori tersebut sesuai dengan hasil yang diperoleh dari penelitian madu Sumbawa ini, dimana warna madu dari pulau Moyo lebih gelap daripada dari daerah lain (Lape, Tepal dan Punik).

\section{Vitamin C}

Asam askorbat (vitamin C) bertindak sebagai antioksidan dengan cara mendonasikan dua electron dari ikatan rangkap diantara karbon ke-2 dan ke-3, pendonoran elektron ini yang mencegah senyawa lain teroksidasi. Oksidasi vitamin $\mathrm{C}$ ini menghasilkan senyawa radikal bebas baru yaitu semidehydroascorbic atau radikal ascorbyl yang lebih stabil daripada radikal bebas lain dan tidak bertahan lama (Padayatty, S.J. et al., 2013; Siti, N. dkk., 2016). Kandungan vitamin $C$ pada madu dari beberapa kecamatan di Kabupaten Sumbawa dapat dilihat pada grafik di bawah:

32.72

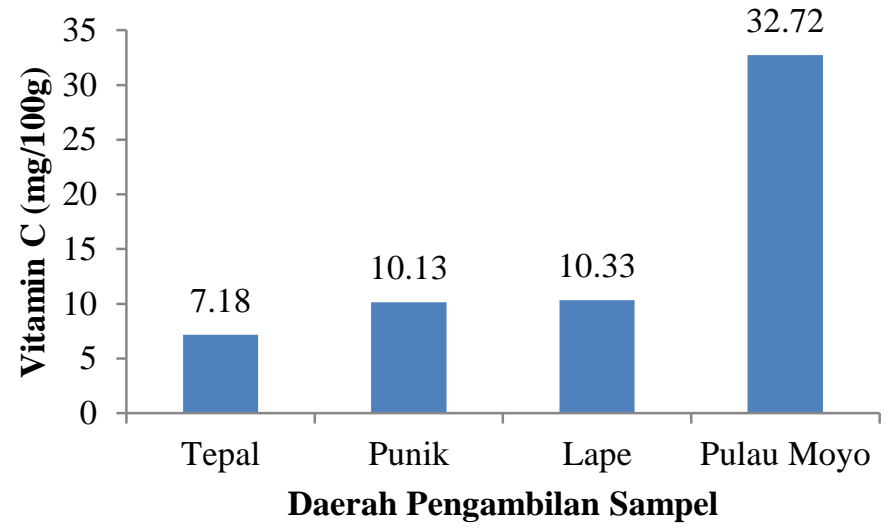

Gambar 6. Kadar Vitamin C (mg/100g) pada Sampel Madu

Dari hasil tersebut dapat dilihat bahwa kadar vitamin C pada sampel madu dari Pulau Moyo, diikuti sampel dari Kecamatan Lape, Punik dan Tepal. Hasil ini sesuai dengan aktivitas antioksidan madu, dimana aktivitas antioksidan (\% penghambatan dan IC50) madu dari Pulau Moyo paling tinggi daripada sampel madu daerah lain. Tetapi hasil ini lebih kecil daripada penelitian-penelitian sebelumnya. Vitamin $\mathrm{C}$ pada madu Tualang, Gelam dan akasia dari Malaysia mengandung 52,2 - 67,4 mg/100g). Madu dari Nigeria mengandung 18,52 - 25,16 $\mathrm{mg} / 100 \mathrm{~g}$ vitamin C. Vitamin C pada madu sangat sensitif terhadap penyimpanan dan proses, sehingga jarang dideteksi pada madu yang sudah mengalami proses pengolahan seperti penyaringan dan pemanasan (Buba, F. et al., 2013; Chua, L.S. et al., 2013).

\section{KESIMPULAN}

Kesimpulan yang diperoleh dari penelitian Identifikasi Senyawa Antioksidan Madu Hutan di Kecamatan Lopok Sumbawa ini antara lain:

a. Madu hutan Sumbawa dari Pulau Moyo memiliki kandungan senyawa fenol dan aktivitas antioksidan yang lebih tinggi daripada madu dari Lape, Tepal dan Punik.

b. Aktivitas antioksidan, kandungan senyawa fenolik dan vitamin $\mathrm{C}$ madu hutan di beberapa kecamatan Kabupaten Sumbawa Besar lebih kecil daripada penelitian di daerah lain.

c. Perlu adanya perbaikan mutu madu hutan Sumbawa

\section{DAFTAR PUSTAKA}

Campone, L. et al., 2014. Determination of Phenolic Compounds in Honey Using Dispersive Liquid-Liquid

Microextraction. Journal of Chromatography A 1334: $9-15$

Chayati, I. dkk., 2014. Kandungan Komponen Fenolat, Kadar Fenolat Total dan Aktivitas Antioksidan Madu dari Beberapa Daerah di Jawa dan Sumatera. MGMI Vol. 6 No.1: 11 - 24.

Buba, F. et al., 2013. Analysis of Biochemical Composition of Honey Samples From North-East Nigeria.Biochemistry and Analytical Biochemistry Vol. 2 Issue 3. 
Chua, L.S., Rahaman, N.L.A., Adnan, N.A., and Tan, T.T.E., 2013. Antioxidant Activity of Three Honey Samples in Relation with Their Biochemical Components. Journal of Analytical Methods in Chemistry Vol. 13: 1-8

Darmawan, S. dan Agustarini, R., 2011. Penurunan Kadar Air Madu Hutan Alam Sumbawa. Prosiding Seminar Nasional Peranan Hasil Litbang HHBK dalam Mendukung Pembangunan Kehutanan: 313-321

Ferreira, I.C.F.R. et al., 2009. Antioxidant Activity of Portuguese Honey Samples: Different Contributions of the Entire Honey and Phenolic Extract. Food Chemistry Vol. 114 issue 4: 1438 -1443

Hussein, S.Z., Yusoff, K.M., Makpol, S., and Yusof, Y.A.M., 2011. Antioxidant Capacities and Total Phenolic Contents Increase with Gamma Irradiation in Two Types of Malaysian Honey. Molecules Vol. 16: 6378-6395

Khalil, M.I., Sulaiman, S.A., and Boukraa, L., 2010. Antioxidant Properties of Honey and its Role in Preventing Health Disorder. The Open Nutraceuticals Journal Vol. 3: 6-16

Khalil, MD.I. et al., 2012. Content and Antioxidant Properties of Processed Tualang Honey Collected From Different Regions in Malaysia. International Journal of Pharmacy and Pharmaceutical Sciences Vol. 4: 214 219.

Kumazawa, S. et al., 2012. Antioxidant Activity in Honeys of Various Floral Origins: Isolation and Identification of Antioxidants in Peppermint Honey. Food Science and Technology Research Vol. 18 (5): 679 - 685.

Lachman, J. et al., Contents of Major Phenolic and Flavonoid Antioxidants in Selected Czech Honey. Czech Journal of Food Science Vol. 28: 412 - 426

Marshall, S.M., 2013. Identification and Concentration of Phenolic and Carbonyl Compounds in Florida Honeys. Thesis-University of Florida: Florida

Moniruzzaman, M. et al., 2013. Physicochemical and Antioxidant Properties of Malaysian Honey Produced by Apis cerana, Apis dorsata and Apis melifera. BMC Complementary and Alternative Medicine Vol. 13: 1 - 12

Nagai, T. et al., 2012. Functional Property of Honey from Echium vulgare. Food and Nutrition Science Vol. 3: 614 - 620

Nascimento, D.L. et al., 2012. Extreme Effects of Season on The Foraging Activities and Colony Productivity of a Stingless Bee (Melipona asilvai Moure, 1971) in Northeast Brazil. Psyche: A Journal of Entomology Vol. 2012 artile ID 267361

Neupane, B.P. et al., 2015 Antioxidant Properties of Honey From Different Altitudes of Nepal Himalayas. Polish Journal of Food and Nutrition Science Vol. 65 No.2: 87 - 91

Pontis, J.A., Costa, M.A., Silva, S.J.R., and Flach, A., 2014. Color, Phenolic, Flavonoid Content and Antioxidant Activity of Honey from Roraima, Brazil. Food Science and Technology Vol. 34(1): 69-73

Prica, N. et al., 2014. Moisture and Acidity as Indicators of the Quality of Honey Originating From Vojvodina Region. Arhiv Veterinarske Medicine Vol. 7 No.2: 99 -109

Puskadija, Z. et al., 2007. Influence of Weather Conditions on Honey Bee Visits (Apis melifera carnica) During Sunflower (Helianthus annuus L.) Blooming Period. ISSN 1330-7142

Sime, D., Atlabachew, M., Abshiro, M. R., and Zewde, T., 2015. Total Phenols and Antioxidant Activities of Natural Honeys and Propolis Collected from Different Geographical Regions of Ethiopia. Bull Chem Soc Ethiop. 29 (2): 163-172.

Siti, N. dkk., 2016. Penetapan Kadar Vitamin $C$ pada Jerami Nangka (Artocarpus hetertopophyllus L.). Jurnal Farmasi Sains dan Praktis Vol.II No1

Trimanto dan Sialiaan, F.A., 2017. Botanical Survey in Moyo Island, West Nusa Tenggara, Indonesia: Inventory of Flora Collection at Forest. The Journal of Tropical Life Science Vol. 7 No.2: $158-166$

Wiriadinata, H. dkk. 2013. Floristic Study of

West Sumbawa, Indonesia. A Journal of

Taxonomic Botany, Plant Sociology and Ecology Vol. 13(5): 391-455 
JURNAL TAMBORA Vol 2 № 3 Desember 2017 